\title{
Relationship between postural control in upright stance and virtual reality in post-stroke individuals
}

\section{Relação entre desempenho do controle postural em pé e em realidade virtual em indivíduos pós-AVC}

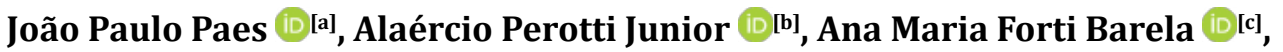 \\ José Angelo Barela (iD [a]* \\ [a] Universidade Estadual Paulista Júlio de Mesquita Filho (UNESP), Rio Claro, SP, Brazil \\ [b] Fundação Hermínio Ometto (FHO/UNIARARAS), Araras, SP, Brazil \\ [c] Universidade Cruzeiro do Sul (UNICSUL), São Paulo, Brazil
}

\section{Abstract}

Introduction: Considered the second leading cause of death worldwide, stroke leads to several consequences resulting from the injury in regions responsible for the processing of sensorimotor information, leading to deficits in the maintenance and performance of postural control. Objective: To relate the performance of postural control during upright stance and a virtual reality task in post-stroke individuals. Method: Nine post-stroke individuals, aged 30 to 76 years, characterized by the Berg balance scale, Fugl - Meyer scale and Mini Mental State Examination participated in this study. Postural performance was measured by the center of pressure under bipedal conditions, in anteroposterior and mediolateral directions and unipedal with the affected and unaffected sides, using a force platform. Virtual reality performance was measured by distance and time required to perform a task in the Nintendo Wii ${ }^{\circledR}$. Results: Revealed significant correlations between distance and displacement time of the affected side (distance $\mathrm{x}$ disc_affected $=0.667 \mid \mathrm{p}=0.025$; time $\mathrm{x}$ disc_affected $=0.683 \mid \mathrm{p}=0.021$ ) and between variables time and mean amplitude of mediolateral oscillation (time $\mathrm{x}$ amo_ml $=-0.733 \mid \mathrm{p}=0.012$ ), time and mediolateral and anteroposterior mean velocity (time

*JPP: MS, e-mail: paesjopa@gmail.com APJ: PhD, e-mail: alaercioperotti@gmail.br AMFB: PhD, e-mail: ambarela@gmail.com JAB: PhD, e-mail: jose.barela@unesp.br 
$\mathrm{x} v \mathrm{vm}_{-} \mathrm{ml}=-0.617 \mid \mathrm{p}=0.038$; time $\mathrm{x}$ vm_ap $=-0.833 \mid \mathrm{p}=0.003$ ) and between time and area (time $\mathrm{x}$ area $=$ $-0.633 \mid p=0.034)$. Conclusion: the performance of standing postural control in post-stroke individuals, represented by measures of weight discharge and variables of postural control, presented a significant relation with the variables of virtual reality.

Keywords: Postural Control. Stroke. Virtual Reality.

\section{Resumo}

Introdução: Tido como a segunda maior causa de morte no mundo, o Acidente Vascular Cerebral tem suas consequências resultantes da lesão em regiões responsáveis pelo processamento das informações sensório-motoras, acarretando déficits na manutenção e desempenho do Controle Postural. Objetivo: Relacionar o desempenho do controle postural em pé e uma tarefa em realidade virtual em indivíduos pós-AVC. Método: Participaram 9 indivíduos em condição de pós-AVC com idades entre 30 a 76 anos, caracterizados por meio da escala de equilíbrio de Berg, Escala de Fugl-Meyer e Mini-Exame de Estado Mental. O desempenho postural foi medido através do deslocamento do centro de pressão nas condições bipodal, nas direções ântero-posterior e médio-lateral, e unipodal, com o lado afetado e não afetado, por meio de uma plataforma de força. O desempenho em realidade virtual, medido por distância e tempo, foi realizado por meio do console Nintendo Wiiß. Resultados: Revelaram correlações significativas entre as variáveis distância e tempo de deslocamento do lado afetado (distância $\mathrm{x}$ desc_afetado=0,667 | $p=0,025$; tempo $\mathrm{x}$ desc_afetado=0,683 / $p=0,021$ ) e entre as variáveis tempo e amplitude média de oscilação médio-lateral (tempo х amo_ml =-0,733 / p=0,012), tempo e velocidade média médio-lateral e ântero-posterior (tempo x vm_ml =-0,617 | $p=0,038$; tempo x vm_ap= -0,833 | $p=0,003$ ) e entre tempo e área (tempo x área $=-0,633$ | $p=0,034$ ). Conclusão: Há relação entre o desempenho do controle postural, mensurado quantitativamente a partir de uma plataforma de força, e o desempenho em tarefa virtual pé em indivíduos pós-AVC.

Palavras-chave: Controle Postural. Acidente Vascular Cerebral. Realidade Virtual.

\section{Introduction}

Considered as the second leading cause of death in the world [1], the Stroke can be due to a blood restriction (anoxic-ischemic), resulting from a vascular failure to supply the demand for oxygen and substrates necessary for the cerebral tissue, or hemorrhagic, where there is blood leakage into or around the structures of the central nervous system $[2,3]$. Stroke can cause cell damage and neurological complications. Clinically, there are several possibilities for the development of pathological conditions, which are commonly associated with mental, perceptual, language, sensory and motor functions $[4,5]$.

The resulting deficits in motor capacity in poststroke individuals resulting from the injury in regions responsible for the processing of sensorimotor information determine variable disabilities depending on their extension, which can be characterized by changes in voluntary motor control with paralysis or paralysis of the contralateral side of the lesion (hemiplegia or hemiparesis) [6,7]. Hemiparesis is the most common clinical resulting from a post-stroke and the motor act in this condition is hampered by muscle weakness, sensory deficits, spasticity, synergistic movements, selective movements, loss of balance and deficits in postural maintenance [7].

Postural control involves controlling the position of the body in space for the dual purpose of stability and orientation $[5,8]$ using multiple sensory references, derived from gravity, support surface and the body's relationship with the environment. An object is in equilibrium when it is capable of maintaining balanced its center of mass (CM), in which the total body mass is converged and projected within its support base, being at rest (static balance) or in stable movement (dynamic balance) [7]. The neural components essential for human orthostasis involve 
motor processes that include synergies of the muscular response and sensory processes covering the visual, vestibular and somatosensory systems and integration processes at a higher level $[9,10]$. After a stroke there are deficits in responses inherent to postural control that can be delayed in the paretic limb and the synergistic organization of the muscles of the paretic limb can also be interrupted [9].

The use of Virtual Reality (VR) has being suggested as a possibility of intervention with specific frames of motor-functional changes, being complementary to the conventional methods already established [11] but, even so, the relationship between performance measures of Postural Control and VR are poorly described in the literature. Gait and posture training with weight suspension associated with VR performed with a television placed in front of a treadmill simulating a daily environment, with pedestrians, buildings and vehicle traffic, showed significant improvements in speed and duration of gait and in balance of participants who, during exposure to VR, received feedbacks about their gait and posture condition [12]. The explanation for the effectiveness of this form of intervention is based on the theory of reorganization mediated by mirror neurons responsible for motor imagery, that is, imagination or visualization of movements that facilitate learning [13]. Thus, VR brings with it the possibility of performing a reliable and methodologically valid task for academic purposes [14] in addition to being pointed out in the literature as being safe and viable for post-stroke individuals $[15,16]$ and is a potential new tool for obtaining postural performance measures in a clinical setting, corroborating investigations on the subject.

Knowing that the posture of post-stroke individuals in the standing position is characterized by an increase in the displacement of the center of mass which leads to difficulties in postural control and, consequently, asymmetry in load transfers, attributing greater weight distribution in the non-paretic member $[17,18]$, the present study sought to examine a possible relationship between the performance of standing postural control in unipodal and bipedal conditions in a postural control task performed in the VR environment in post-stroke individuals. The hypothesis of this study is that due to deficits in maintaining postural control post-stroke individuals have a significant relationship between the performance of standing postural control in both conditions and performance in a postural control task performed in VR.

\section{Method}

\section{Participants}

Nine individuals with chronic post-stroke condition participated in this study (three females and six males, aged between 30 and 76 years), being seven with hemiparesis present on the left side and two on the right side. As an inclusion criterion participants should be an integral part of the patients treated by the physiotherapy clinic of Fundação Hermínio Ometto - Uniararas, have visual and auditory capacity, maintain standing posture without the aid of devices and be able to perform the proposed task.

After identifying the possible participants, the objectives and procedures were explained and, if they agreed to participate in the study, the participant was invited to sign an Informed Consent Form, approved by the Institutional Ethics Committee (CAAE 47490615.2. 0000.5385). To characterize the sample, clinical information of each participant was obtained from the medical record and the Mini-Mental State Examination (MMSE) $[19,20]$, the Fugl-Meyer Scale [21] and the Berg Scale [22] were used (Table 1).

Table 1 - Characterization of the sample from the clinical record and application of tests to classify the degree of injury and functional capacity. Subjects (total number of participants), sex (male and female), affected side and mean values and standard deviation (age, Fugl-Meyer, Berg and Mini-Mental State Examination)

\begin{tabular}{|c|c|c|c|c|c|c|c|c|}
\hline \multirow[t]{2}{*}{ Subjects } & \multicolumn{2}{|c|}{ Sex } & \multicolumn{2}{|c|}{ Affected Side } & Age & Fugl-Meyer & Berg & MMSE \\
\hline & $M$ & $\mathrm{~F}$ & $\mathrm{R}$ & $\mathrm{L}$ & \multicolumn{4}{|c|}{ Mean \pm SD } \\
\hline 9 & 6 & 3 & 2 & 7 & $56.2 \pm 13$ & $151.7 \pm 23.3$ & $42.6 \pm 7$ & $24.7 \pm 4.1$ \\
\hline
\end{tabular}

Note: $\mathrm{M}=$ male; $\mathrm{F}=$ female; $\mathrm{R}=$ right; $\mathrm{L}=$ left; $\mathrm{SD}=$ standard deviation; MMSE = Mini-Mental State Examination. Source: prepared by the authors based on the study. 
Procedures

Participants were taken to a room at the institution's physiotherapy clinic and after signing the informed consent form performed the sample characterization tests. To test the cognitive functions of the participants the Mini-Mental State Examination (MMSE) was applied, which consists of questions typically grouped into seven specific categories: time orientation, location orientation, three-word record, attention and calculation, memory of the three words, language and visual constructive capacity. The MMSE score can vary from 0 to 30 points, with a value less than 23 being indicative of dementia [19,20].

Participants were assessed for severity of the sensory-motor sequela of the stroke, using the Fugl-Meyer Scale (EFM). This scale is divided into 5 domains: Motor function, sensitivity, balance, range of motion and pain. The items are scored on an ordinal scale from 0 to $2(0=$ no performance; 1 = partially performed, 2 = complete performance), totaling 226 points [21].

The performance of the participants' balance from the functional point of view was evaluated using the Berg balance scale. It includes 14 items that correspond to different balance tasks, which have a strong relationship with the Activities of Daily Living (ADLs). They are: sit and stand, stand without support, sit without support with your feet on the floor, orthostatism for sitting, postural transfers, stand without support with eyes closed, stand without support with your feet together, reach forward with your arm outstretched, pick up an object on the floor, turn to look behind your right and left shoulder, rotate $360^{\circ}$, up and down a step, remain upright with one foot forward, remain standing one leg. Each item has an ordinal scale of five options that assess the participant's performance between 0 and 4 points. Therefore, the maximum score that the participant can reach is 56 points [22].

After these initial assessments, participants performed an assessment of weight baring and performance of postural control and a virtual reality task. For the assessment of postural control, the participants had to position themselves on a force platform (Kistler, model $9286 \mathrm{~A}$ ), with their arms extended loose at their sides as static as possible in two support conditions. In the first condition, called unipodal, participants stepped with one foot (affected side or unaffected side) on the force platform and the other foot on a wooden platform positioned beside and at the same height as the force platform.
Two attempts were obtained, one for each side (affected and unaffected) positioned on the platform. In the other condition, called bipedal, the participants supported both feet on the force platform, obtaining two attempts in this condition. In all attempts, participants remained with their eyes open, fixing a target of $5 \mathrm{~cm}$ in diameter, located at eye level, 1 meter away from the participant. Participants were asked to remain as static as possible throughout the attempt, each lasting $30 \mathrm{sec}-$ onds. Between attempts, participant stepped out of the force plate and if necessary, could sit down to avoid any fatigue effect. The force platform data were collected at frequency of $100 \mathrm{~Hz}$, using an acquisition plate (NI USB-6251 BNC, National Instruments, Inc.) and a specific program developed in the LabView ${ }^{\circledR}$ environment (National Instruments, Inc.).

Right after the end of data collection on the force platform, on the same day, participants performed the virtual task using the Nintendo Wii ${ }^{\circledR}$ video game provided with a balance board system. This system consisted of a motion sensor which allows the representation of the displacement of the player's center of mass in a virtual environment, so that an "avatar" corresponding to the individual in a virtual environment can move and achieve the task objective to be performed. Such a mechanism makes it possible to perform a reliable and methodologically valid task for academic purposes [23], in addition to being pointed out in the literature as being safe and viable for post-stroke individuals [23,24].

A projector (Benq ${ }^{\circledR}$ model MX 660) was used to project the virtual environment on a projection screen on the premises of the Physiotherapy clinic. The projector was arranged so that the projection was directed in front of the participant. Calibrations were performed so that the projection was $2.2 \mathrm{~m}$ long by $2.5 \mathrm{~m}$ wide. The participants were positioned at a distance of approximately $2.5 \mathrm{~m}$ from the projection.

The game chosen for this study was the Balance Bubble from the Wii Fit Plus collection as it is a task that involves postural control that requires alteration of the participant's center of mass, involving anticipatory postural responses to voluntary movements, which tend to be destabilizing, in order to maintain the stability of the organism during movement [4]. The dynamics of this game occurs through the multidirectional displacement of the pressure center, making it possible to control an avatar inside a bubble. With this displacement it is allowed to make the avatar move along a path represented by the current of a river. Thus, the objective of the task is to make the avatar travel as far as possible 
through the current aiming to reach the end of the route without touching the river banks and if it touched, a new attempt was initiated. For the present study, only the Beginner difficulty level was used, which has the lowest level of complexity.

After the familiarization period with the task the participants were asked to move according to what was requested in the game: to follow a river without touching its edges for most of the possible route, always aiming at the finish line, representing the end of the attempt. Each participant made five attempts at the game, and from these, the distance and the time elapsed until the attempt was completed were obtained.

\section{Data analysis}

From the data of the force platform, the total vertical force was obtained for the two attempts of the unipodal condition. For attempts at the bipedal condition, the center of pressure (CoP) was obtained for the anteroposterior (AP) mediolateral (ML) directions for each attempt. Subsequently, the total vertical force and the CoP were filtered with a digital Butterworth filter, 4 in the order and cutoff frequency of $5 \mathrm{~Hz}$.

For the unipodal condition, the average of the total vertical force was obtained for each attempt indicating the body weight discharged on the force platform (affected side and unaffected side) and normalized by the total weight. In this way, the percentage of the average weight unloaded on the platform was obtained along the attempt for each side of the participant's body.

For the bipedal condition, the performance of postural control during the maintenance of an upright posture during each attempt was verified by obtaining the variables amplitude and mean oscillation speed and displacement area. The mean amplitude of oscillation (AMO) was obtained by subtracting a first order polynomial and the mean of all values of the attempt and, subsequently, obtaining the standard deviation. The AMO, therefore, corresponds to the variance of the data, with lower values indicating smaller magnitude of body oscillation and vice versa, obtained for the directions AP and ML and given in millimeters. The mean speed of oscillation was calculated by obtaining the total trajectory of the displacement of the CoP, throughout the trial, and dividing by the total trial time. The mean velocity (MV) was also obtained for the AP and ML directions and the mean unit was mm/s. Finally, the displacement area was calculated using the statistical method involving analysis of the main components, in which an ellipse that encompasses $85 \%$ of the CP data for the AP and ML directions concurrently was obtained and, subsequently, the area of this ellipse was calculated. The larger the area, it is inferred that the greater the oscillation; the unit of measurement of this variable is $\mathrm{mm}^{2}$.

The variables AMO, mean speed and displacement area were obtained for each of the two attempts in the bipedal condition. Subsequently, the average between the two attempts was obtained and used for further analysis. The procedures for processing the data and obtaining the variables were performed using routines written for specific purposes, using MatLab ${ }^{\circledR}$ software (Mathworks, Inc).

The VR task was performed using the Nintendo $\mathrm{Wii}^{\circledR}$ provided with a Balance Board with the game Balance Bubble. The dynamics of this game takes place through the multidirectional displacement of the pressure center and, thus, it is possible to control an avatar inside a bubble in order to travel a path. The distance covered and the time required to play the game were obtained for each attempt. Subsequently, the mean of the five attempts made was obtained for both variables and used for further analysis.

\section{Statistical analysis}

Initialy, descriptive analysis was performed to obtaining the mean and standard deviation for each variable used in the study. Subsequently, Spearman's correlation analysis obtaining the rho coefficient was performed among the variables of interest. Thus, as variables of the virtual reality task, distance and elapsed time, they were related to a weight bearing of the affected and unaffected sides. Still, as variables of the virtual task performed, distance and elapsed time, they were also related to performance variables of the AMO postural control, mean speed, for AP and ML variables, and area. All analyzes were performed using the SPSS software and the level of significance was maintained at 0.05 .

\section{Results}

Table 2 shows the average values referring to the variables of virtual reality and the performance of postural control of the participants of the present study. 
Table 2 - Average values ( \pm standard deviation) of the variables obtained in the performance of the virtual reality task, weight unloading and the performance of postural control

\begin{tabular}{lc}
\hline Virtual Reality & Mean \pm Standard Deviation \\
\hline Time (seconds) & $326 \pm 304.2$ \\
Concluded & $33.2 \pm 21.5$ \\
\hline Discharge of weight & $60.3 \pm 8.2$ \\
\hline $\begin{array}{l}\text { Discharge of the unaffected } \\
\text { limb weight (\%) }\end{array}$ & $40.8 \pm 7.3$ \\
$\begin{array}{l}\text { Discharge of the affected limb } \\
\text { weight (\%) }\end{array}$ & $2.1 \pm 0.55$ \\
\hline Postural Control & $1.5 \pm 0.52$ \\
\hline $\begin{array}{l}\text { Mean amplitude of oscillation } \\
\text { AP (mm) 0stural Control }\end{array}$ & $9.3 \pm 3.3$ \\
$\begin{array}{l}\text { Mean amplitude of oscillation } \\
\text { ML (mm) Age }\end{array}$ & $5.7 \pm 1.7$ \\
$\begin{array}{l}\text { Mean speed of oscillation AP } \\
\text { (mm/s) }\end{array}$ & $83.0 \pm 69.3$ \\
$\begin{array}{l}\text { Mean speed of oscillation ML } \\
\text { (mm/s) }\end{array}$ & Area (mm/s²)
\end{tabular}

Note: Virtual Reality in meters and seconds; Weight discharge of affected and unaffected limbs in percentage; Variables of postural control in millimeters (mean amplitude of anteroposterior and mediolateral oscillation), millimeters per second (mean speed of anteroposterior and mediolateral oscillation) and millimeters per second squared (total area). Source: prepared by the authors based on the study.

Table 3 presents the data related to the correlation analysis carried out between as VR variables (distance and time) and as weight unloading, according to the affected and unaffected side (disc_affected and disc_unaffected). It is possible to identify a positive relationship between distance $\mathrm{x}$ disc_affected (rho $=0,667$ ), with a significance value of $p=$ 0.025 . Also note that the relationship between time $\mathrm{x}$ disc_affected was also positive ( $\mathrm{rho}=0.683$ ) and with a significance value of $p=0.021$. The variables of distance and time, when related to a discharge from the unaffected limb, did not show statistically significant coefficients ( $p>0.05$ ), reported no relationship between these variables.

Table 3 - Values of the rho coefficient between the variables of RV and weight unloading

\begin{tabular}{l|cccc}
\hline \multicolumn{5}{|c}{ VR x Discharge of weight } \\
\hline & $\begin{array}{c}\text { distance } \\
\text { x disc } \\
\text { unaffected }\end{array}$ & $\begin{array}{c}\text { distance } \\
\text { x disc } \\
\text { affected }\end{array}$ & $\begin{array}{c}\text { time } x \\
\text { disc } \\
\text { unaffected }\end{array}$ & $\begin{array}{c}\text { time } x \\
\text { disc } \\
\text { affected }\end{array}$ \\
$\begin{array}{l}\text { Correlation } \\
\text { Coefficient } \\
\text { (rho) }\end{array}$ & 0.350 & 0.667 & -0.450 & 0.683 \\
\hline Sig. & 0.178 & $0.025^{*}$ & 0.112 & $0.021^{*}$ \\
\hline
\end{tabular}

Note: VR = Virtual Reality; desc_n_afocado = displacement of side not affected; desc_af affected = displacement of the affected side; Coef. correlation = Correlation Coefficient; Sig. = Statistically Significant. : * Indicates statistically significant. Source: prepared by the authors based on the study.

Table 4 presents the results of the correlation analysis between the variables of VR (distance and time) and those of postural performance, mediolateral and anteroposterior amplitude, mean of mediolateral and anteroposterior speed and total area (amo_ml, amo_ap, vm_ml, vm_ap and area).

Table 4 - Values of the return coefficient between VR variables and postural control performance variables

\begin{tabular}{|c|c|c|c|c|c|}
\hline \multicolumn{6}{|c|}{ VR x Postural Control } \\
\hline & $\begin{array}{l}\text { distance } x \\
\text { amo_ap }\end{array}$ & $\begin{array}{l}\text { distance x } \\
\text { amo_ml }\end{array}$ & distance $x$ vm_ap & distance $\mathrm{x}$ vm_ml & Distance $\mathrm{x}$ área \\
\hline $\begin{array}{l}\text { Correlation } \\
\text { Coefficient (rho) }\end{array}$ & -0.400 & -0.367 & -0.567 & -0.333 & -0.267 \\
\hline Sig. & 0.14 & 0.17 & 0.06 & 0.19 & 0.24 \\
\hline Correlation & time $x$ amo_ap & time $x$ amo_ml & Time x vm_ap & time x vm_ml & Time x área \\
\hline Coefficient (rho) & -0.483 & -0.733 & -0.833 & -0.617 & -0.633 \\
\hline Sig. & 0.094 & $0.012^{\star}$ & $0.003^{*}$ & $0.038^{*}$ & $0.034^{*}$ \\
\hline
\end{tabular}

Note: VR = Virtual Reality; amo_ap = mean amplitude of anteroposterior oscillation; amo_ml = mean amplitude of mediolateral oscillation; vm_ap = mean anteroposterior oscillation speed; vm_ml = mean speed of mediolateral oscillation; area $=$ total area. Coef. correlation $=$ Correlation Coefficient; Sig. = Statistically Significant. *Indicates statistically significant. Source: prepared by the authors based on the study.

The time analysis $\mathrm{x}$ amo_ml showed a strong and negative relationship (rho $=-0.733$ ) with a significance of $\mathrm{p}=0.012$. The time variable also had a strong relationship with the variables vm_ap and vm_ml (rho $=-0.833$ and -0.617 ), with significance of $p=0.003$ and $p=0.038$, respectively. Finally, the analysis between timex area also shows a strong relationship (rho $=-0.6333$ ) and with significance of $p=0.034$. 


\section{Discussion}

The present study sought to answer whether there is a correlation between the performance of standing postural control and in a task performed in the VR environment in post-stroke individuals using the Nintendo Wii ${ }^{\circledR}$ console provided by the Balance Board. The results indicated (i) a positive and significant correlation between the performance in the VR task (distance and time) and the percentage of weight unloading on the side affected by the injury and (ii) a negative and significant correlation between VR and variables of postural performance, showing that the lower the postural oscillation, the greater the time and distance in performing the virtual task. Based on these results the hypothesis raised in the study of the relationship between performance in a virtual task and performance during the maintenance of standing posture was accepted.

The observed relationship between weight-bearing on the affected limb and performance on the virtual task demonstrates the importance of symmetry between the hemibodies for greater functionality and performance of individuals after stroke. From the results obtained in this study, it is possible to suggested that a better performance in maintaining upright stance is related to a better performance in functional tasks with postural demands. Such finding also occurred in a previous study, revealing relationship between trunk control, functional performance and balance in stroke patients, which may be associated with asymmetries that alter the biomechanics of movement, deviating the center of mass from the support base, making postural adjustment reactions difficult, which can interfere with performance of activities of daily living (ADL's) [24, 25]. Moreover, our results also indicated an important relation with the weight unloading of the affected side. The lack of relationship between performance in the virtual task and the unloading of weight from the unaffected side should be better examined to furhter understand such finding. One explanation could be that each individual, considering the possible postural changes resulting from stroke, seeks different strategies for the efficient maintenance of standing posture from the unaffected side, which does not seem to occur with the affected side. Yet, further investigations are necessary because it is important to consider experimental designs whose models contemplate the relationship between the effect of learning the task on postural performance and, not having presented this, was a limitation of the present study.
In our experimental protocol, those who oscillated the most during the recording of the postural variables and task in virtual reality had less control of the avatar's actions and, therefore, could not even control the avatar to a minimum distance so that if it could obtain a measure of performance in the task. Understanding postural control as the control of body segment arrangements based on the supply of sensory information from different sources, it can be said that this allows us to form an internal representation of the external world, reporting and recognizing the position and movement of each body part [26 - 28] in favor of efficient orthostatism and, deficits in this scheme, can explain the results found. To perform the task in VR, as well as in most functional tasks, it is necessary to maintain the vertical orientation of the body, which consequently demands the need for action of visual, vestibular and somatosensory systems [4] and a poor sensory integration may have contributed to the low performance in performing the virtual environment task, a hypothesis that needs further investigation.

The results of the present study indicated a relationship between performance in maintaining standing posture and performing the task in a virtual environment, which corroborates the use of instruments based on these systems in clinical settings. The use of VR for rehabilitation is already extensively investigated in the literature, this is due to the characteristic of a new possibility of intervention amid traditional methods, but little is discussed about the use of these platforms as instruments for assessing postural performance. The literature is already consistent in showing that the ability to perform a postural control task at higher levels of complexity causes post-stroke individuals to differ negatively from healthy individuals [15] but, the effects of the injury side in relation to learning of postural control tasks, performed in a virtual environment, show that post-stroke individuals have the ability to learn a postural control task similar to healthy individuals and that the injury side does not affect the learning of this task [15].

Seeking to reinforce the use of accessories used in the VR environment as an assessment instrument and not just an intervention, one of the most significant attributions given to the Wii Balance Board platform occurred due to its great potential for use in the measurement of postural variables, once in standing on the platform, due to sensors distributed under it, it is possible to measure anteroposterior and mediolateral oscillations of the center of pressure, making it an even 
more mobile and cheaper alternative facing the already established conventional force platforms, which makes it viable in clinical settings [29]. Through a study, using a Balance Board platform and software developed in a MatLab ${ }^{\circledR}$ environment (Mathworks, Inc), researchers validated the use of the Balance Board as alternatives to traditional platforms when comparing CoP data from it with o a conventional force platform, which presented significantly relevant results [30] confirming that the use of VR environments and accessories from these platforms appear as a real possibility of postural assessment in a clinical environment.

\section{Conclusion}

From the results obtained, it was possible to confirm the initial hypothesis raised by the present study that, from the impairment of postural maintenance of post-stroke individuals, which can be represented by the deficit in the maintenance of the center of mass and the load distribution asymmetrical within a support base, the performance of postural control correlates with a postural control task performed in virtual reality. As already mentioned, studies with greater depth should be considered in order to investigate whether the effect of a periodized program within the proposed task would alter, for example, the effect of the relationship evidenced by the present study.

\section{References}

1. Almeida SRM. Análise Epidemiológica do Acidente Vascular Cerebral no Brasil. Rev Neurol. 2012;4:481-2.

2. Chaves MLF. Acidente Vascular Encefálico: conceituação e fatores de risco. Rev Bras Hipertens. 2000;7(4):372-82.

3. Leite HR, Nunes APN, Corrêa CL. Perfil epidemiológico de pacientes acometidos por acidente vascular encefálico cadastrados na Estratégia de Saúde da Família em Diamantina, MG. Fisioter Pesqui. 2009;16(1):34-9.

4. Sardi MD, Schuster RC, Alvarenga LFC. Efeitos da realidade virtual em hemiparéticos crônicos pósacidente vascular encefálico. Rev Bras Cienc Saude. 2012;10(32):29-35.
5. Shumway-Cook A, Woollacott MH. Controle Motor: Teoria e Aplicações Práticas. 3rd ed. Barueri: Manole; 2010. 632 p.

6. Mota RS, Conceição TMA, Soares TMC, Lima e Silva I, Cardoso FB, Beresford H. Uma avaliação acerca do perfil somatossensorial de indivíduos hemiparéticos. Motri. 2010;6(3):13-9.

7. Polese JC. Parâmetros Biomecânicos e Percepção de Hemiparéticos Crônicos com o uso de dispositivos Auxiliares na Marcha (master's thesis ). Belo Horizonte: Universidade Federal de Minas Gerais; 2011.126 p.

8. Chou SW, Wong AMK, Leong CP, Hong WS, Tang FT, Lin TH. Postural control during sit-to-stand and gait in stroke patients. Am J Phys Med Rehabil. 2003;82(1):42-7.

9. Farias NC, Rech I, Ribeiro BG, Oliveira CS, Menna W, Albuquerque CE, et al. Avaliação postural em hemiparéticos por meio do software SAPo - Relato de caso. ConScientiae Saude. 2011;8(4):649-54.

10. Gawryszeweski LG, Lameira AP, Ferreira, M, GuimaraesSilva S, Conde EFQ, Pereira JRA. A Compatibilidade Estímulo-Resposta como Modelo para o Estudo do Comportamento Motor. Psicol USP. 2006;17(4):103-21.

11. Sveistrup H. Motor rehabilitation using virtual reality. J Neuroeng Rehabil. 2004;1(1):1-8.

12. Walker ML, Ringleb SI, Maihafer GC, Walker R, Crouch JR, Van Lunen B, et al. Virtual Reality-Enhanced Partial body Weight-Supported Treadmill Poststroke: Feasibility and Effectiveness in 6 Subjects. Arch Phys Med Rehabil. 2010;91(1):115-22.

13. Souza LB, Paim CRP, Imamura M, Alfieri FM. Uso de um ambiente de realidade virtual para a reabilitação de acidente vascular encefálico. Acta Fisiatr. 2011;18:217-9.

14. Deutch JE, Brettler A, Smith C, Welsh J, John R, GuarreraBowlby P, et al. Nintendo Wii Sports and Wii Fit Game Analysis, Validation, and Application to Stroke Rehabilitation. Top Stroke Rehabil. 2011;18(6):701-19.

15. Saposnik G, Cohen LG, Mamdani M, Pooyania S, Ploughman M, Cheung D, et al. Efficacy and safety of non-immersive virtual reality exercising in stroke rehabilitation (EVREST): a randomized, multicentre, single blind, controlled trial. Lancet. 2016;15(10):1-9.

16. Pérennou D. Weight bearing asymmetry in standing hemiparetic patients. J Neurol Neurosurg Psychiatry. 2005;76(5):621. 
17. Hachisuka K, Umezu Y, Ogata H. Disuse Muscle Atrophy of Lower Limbs in Hemiplegic Patients. Arch Phys Med Rehabil. 1997;78(1):13-8.

18. Ioffe ME, Chernikova lA, Umarova RM, Katsuba NA, Kulikov MA. Learning postural tasks in hemiparetic patients with lesions of left versus right hemisphere. Exp Brain Res. 2010;201(4):753-61.

19. Folstein MF, Folstein SE, Mchugh PR. Mini-Mental State: a pratical methos for gradind the cognitive state of patients for the clinician. J Psychiatr Res. 1975;12(3):189-98.

20. Tombaugh TN, Mcintyre NJ. The mini-mental state examination: a comprehensive review. J Am Geriatr Soc. 1992;40(9):922-35.

21. Fugl-Meyer AR, Jääskö L, Leyman I, Olsson S, Steglind S. The post-stroke hemiplegic patient. Scand J Rehabil Med. 1975;7(1):13-31.

22. Berg K. Measuring balance in elderly: validation of an instrument (master's thesis). Montreal: McGill University; 1993.

23. Saposnik G, Teasell R, Mandani M, Hall J, Mcilroy W, Cheung D, et al. Effectiveness of virtual reality using Wii gaming technology in stroke rehabilitation: a pilot randomized clinical trial and proof of principle. Stroke. 2010;41(7):1477-84.
24. Pompeu JE, Alonso TH, Masson BI, Pompeu SMAA, Torriani-Pasin C. Os efeitos da realidade virtual na reabilitação do acidente vascular encefálico: Uma revisão sistemática. Motri. 2014;10(4):111-22.

25. Teixeira-Salmela LF, Oliveira ESG, Santana EG, Resende GP. Fortalecimento muscular e condicionamento físico em hemiplégicos. Acta Fisiatr. 2000;7(3):108-18.

26. Mochizuki L, Amadio AC. As informações sensoriais para o controle postural. Fisioter Mov. 2006;19(2):11-8.

27. Mann L, Kleinpaul JF, Teixeira CS, Mota CB. Influência dos sistemas sensoriais na manutenção da postura em gestantes. Fisioter Mov. 2011;24(2):315-25.

28. Soares AV, Hochmüller ACOL, Silva P, Fronza D, Woellner SS, Noveletto F. Biorretroalimentação para treinamento do equilíbrio em hemiparéticos por acidente vascular encefálico: estudo preliminar. Fisioter Pesqui. 2009;16(16):132-6.

29. Goble DJ, Cone BL, Fling BW. Using the Wii Fit as a tool for balance assessment and neurorehabilitation: the first half decade of "Wii-search". J Neuroeng Rehabil. 2014;11:12.

30. Clark RA, Bryant AL, Pua Y, McCrory P, Bennell K, Hunt M. Validity and reliability of the Nintendo Wii Balance Board for assessment of standing balance. Gait Posture. 2010;31(3):307-10.
Received: 02/25/2019

Recebido: 25/02/2019

Approved: $12 / 30 / 2019$

Aprovado: 30/12/2019 